\title{
Proses Hidrokimia pada Air Dolina Kars Gunungsewu di Kabupaten Gunungkidul, Yogyakarta
}

\author{
T. Listyani R.A ${ }^{1 *}$, Purwita Rosa Nugrahani ${ }^{1}$, Irghi Reynaldi Adam ${ }^{1}$, Raras Prabowo ${ }^{1}$ \\ ${ }^{1}$ Teknik Geologi, Institut Teknologi Nasional Yogyakarta
}

\begin{abstract}
Abstrak
Salah satu permasalahan di daerah kars yang menarik untuk dikaji adalah masalah hidrokimia, khususnya pada subbentang alam eksokars yang berupa dolina. Penelitian ini bertujuan untuk mengetahui fenomena proses hidrokimia pada air dolina yang terjadi pada dua sub sistem hidrogeologi Panggang dan Wonosari-Baron, Kabupaten Gunungkidul. Metode yang dilakukan adalah survey hidrogeologi dilengkapi dengan uji sifat fisik/kimia air di laboratorium. Analisis hidrokimia dilakukan menggunakan diagram Piper dan grafik hubungan antar ion. Fasies hidrokimia pada musim kemarau pada umumnya berkembang sebagai fasies $\mathrm{Ca}$, Na-bikarbonat, sedangkan pada musim hujan, air dolina didominasi oleh fasies Ca-bikarbonat. Hidrokimia air dolina sangat dipengaruhi oleh proses pelapukan disolusi batugamping sebagai proses utama, selain adanya pengayaan pada musim kemarau melalui proses evaporasi. Pada musim hujan, presipitasi ikut berperan penting dalam mempengaruhi hidrokimia air dolina melalui proses dilusi. Adapun proses antropogenik hanya menunjukkan intensitas yang kecil.
\end{abstract}

Kata kunci: Antropogenik; disolusi; evaporasi; Gunungsewu; hidrokimia; pelapukan.

\begin{abstract}
One of the interesting problems in the karst area is the hydrochemical problem, especially in the exokarst sub landscape in the form of doline. This study aims to determine the phenomenon of hydrochemical processes in doline water that occurs in Panggang and Wonosari-Baron hydrogeological sub-systems, Gunungkidul Regency. The method used is a hydrogeological survey equipped with a physical / chemical test of water in the laboratory. The hydrochemical analysis was performed using a Piper diagram and a graph of the relationship between ions. In the dry season, the hydrochemical facies generally develop as $\mathrm{Ca}$, Na-bicarbonate facies, while in the rainy season, doline water is dominated by Ca-bicarbonate facies. The hydrochemistry of doline water is strongly influenced by the weathering process of limestone dissolution as the main process, in addition to the enrichment in the dry season through the evaporation process. In the rainy season, precipitation plays an important role in influencing the hydrochemistry of doline water through the dilution process. The anthropogenic process only shows a small intensity.
\end{abstract}

Keywords: Anthropogenic; dissolution; evaporation; Gunungsewu; hydrochemical; weathering.

\footnotetext{
*Korespondensi: lis@itny.ac.id

Diajukan : 30 Desember 2020

Diterima : 27 Januari 2021

Diterbitkan : 31 Maret 2021
} 


\section{PENDAHULUAN}

\section{Latar Belakang}

Bentang alam kars Gunungsewu merupakan kawasan kars di daerah tropis. Salah satu kawasan kars di Indonesia yang paling kompleks dan terbaik serta merupakan kawasan kars tropis adalah kawasan kars Gunungsewu (Kusumayudha dkk., 2015). Di daerah ini, bentang alam kars sangat berkembang, baik berupa eksokars maupun endokars. Salah satu bentang alam eksokars yang mudah ditemukan adalah subbentang alam dolina yang merupakan cekungan lembah di antara bukit-bukit kerucut kars.

Kajian air di daerah kars dapat dilakukan dari sudut pandang kualitasnya. Kualitas air secara kimiawi dilakukan dengan menilai aspek kandungan kimia air (hidrokimia). Studi ini penting dilakukan untuk menunjang potensi sumber daya air di daerah penelitian, karena studi ini mendukung kajian potensi hidrogeologi dan lingkungan di daerah penelitian.

Metode hidrokimia akan membantu pemahaman hidrogeologi suatu daerah. Aspek hidrokimia dapat diketahui dengan melakukan berbagai analisis, interpretasi maupun korelasi komponen kimia airtanah, serta mengetahui berbagai proses hidrokimia yang dikendalikan oleh geologi suatu daerah. Selain terhadap airtanah, kita juga dapat mengetahui berbagai proses hidrokimia yang terjadi pada air permukaan yang terdapat dalam suatu dolina. Relasi air permukaan ini airtanah di sekitarnya juga dapat dianalisis. Hidrokimia air juga berguna untuk menilai potensi kualitas airtanah, yang tentunya sangat bermanfaat bagi masyarakat yang tinggal di daerah penelitian.

Obyek penelitian ini adalah dolina yang ada pada kawasan kars Gunungsewu, khususnya yang termasuk dalam Sub Sistem Hidrogeologi (SSH) Panggang dan SSH Wonosari-Baron. Secara administrasi, daerah penelitian beberapa desa di Kecamatan Purwosari, Panggang maupun Saptosari (Gambar 1).

\section{Maksud dan Tujuan}

Penelitian ini merupakan survei hidrogeologi yang dilakukan pada kawasan bentang alam kars Gunungsewu yang berada di wilayah Kabupaten Gunungkidul. Tujuan survei hidrogeologi ini antara lain adalah mengetahui proses hidrokimia yang mungkin terjadi pada sub sistem hidrogeologi yang diteliti, yang dapat teramati pada sub bentang alam dolina.

\section{TINJAUAN PUSTAKA \\ Hidrogeologi Daerah Gunungsewu}

Berdasarkan pemisahan zona hidrodinamik, pola luahan serta sebaran mata air yang ada, sistem hidrogeologi di daerah Gunungsewu dapat dibagi menjadi 3 sub sistem, dari barat ke timur yaitu SSH Panggang, Wonosari -Baron serta Sadeng (Kusumayudha, 2002). Akuifer yang potensial di daerah Gunungsewu adalah batugamping Formasi Wonosari. Berdasarkan data pemboran, penyebaran caliche di daerah Gunungsewu pada umumnya tidak menerus baik secara vertikal maupun horizontal. Hal ini memungkinkan terbentuknya akuifer menggantung di dalam sistem akuifer bebas batugamping kars. Perbedaan sifat fisik antara akuifer karsik dan akuifer non karsik (caliche) adalah pada jaringan porositasnya, yaitu sistem rongga, dan sistem intergranuler.

Karakter sistem imbuhan air tanah di daerah Gunungkidul telah diteliti oleh Setiawan dkk. (2018). Hasil penelitiannya menunjukkan bahwa airtanah di wilayah tersebut berkaitan dengan sistem imbuhan yang bersifat, menengah maupun regional.

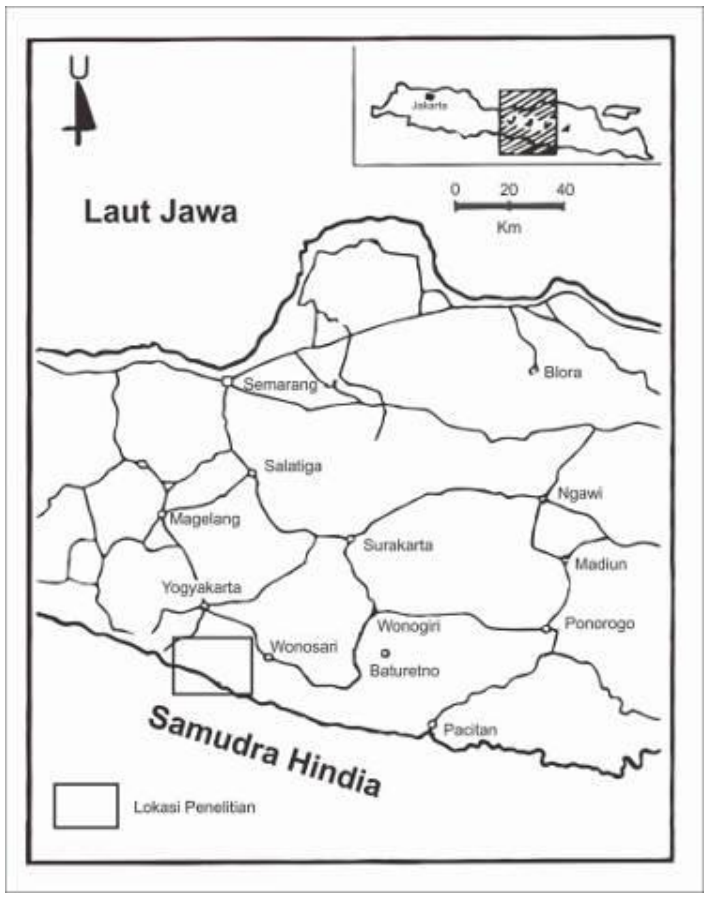

Gambar 1. Lokasi daerah penelitian berada di Kecamatan Purwosari, Panggang dan Saptosari, Gunungkidul. 
Selanjutnya, Setiawan dkk. (2019) juga menyatakan bahwa sebagian besar airtanah pada mata air dan sungai bawah tanah daerah kars berasal dari airtanah yang jenuh terhadap $\mathrm{CaCO}_{3}$ dengan sistem aliran difusi pada zona epikars. Aliran difusi ini kemudian berkembang menjadi aliran airtanah dengan sistem konduit (rongga). Airtanah yang berasal dari sumur bor dominan mengalir secara difusi terutama pada media berpori atau jaringan kekar yang rapat.

\section{Dolina Gunungsewu}

Kars bentang alam di permukaan bumi yang pada umumnya dicirikan dengan adanya depresi tertutup, drainase bawah permukaan, dan gua. Daerah ini dibentuk terutama oleh pelarutan batuan, terutama batugamping. Salah satu bentang alam kars yang berkembang bagus adalah kars Gunungsewu (Pambudi dkk., 2018).

Kars terdiri dari beberapa bentang alam yang sangat unik di dunia, umumnya ditandai oleh bentang alam yang tertentu yang khas. Bentang alam ini dapat ditemukan di permukaan maupun di bawah tanah. Bentuk lahan permukaan umumnya mencakup depresi tertutup/dolina, lubang cekungan/sinkholes, sungai bawah tanah dan mata air kars (Geological Survey, 2019).

Dolina adalah bentang alam paling umum di kawasan kars. Bentuk lahan ini digambarkan sebagai depresi tertutup berukuran (diameter maupun kedalaman) kecil hingga menengah, mulai dari meter hingga puluhan meter. Dolina berfungsi sebagai corong yang memungkinkan terjadinya transmisi langsung air permukaan ke akuifer batuan dasar. Dolina mungkin muncul sebagai bentukan yang terisolasi atau dalam kelompok yang memberikan rona bintik-bintik pada permukaan tanah (Ford dan Williams, 2007).

Gunungsewu memiliki bentang alam yang sangat unik, hal tersebut dicirikan dengan adanya fenomena di permukaan (eksokars) dan bawah permukaan (endokars) yang bervariasi. Fenomena permukaan meliputi bentukan positif, seperti perbukitan kars yang jumlahnya \pm 40.000 bukit yang berbentuk kerucut, yang sering disebut bukit kerucut (conical hill). Bentukan negatifnya berupa lembah-lembah kars dan telaga kars (dolina). Dolina merupakan depresi tertutup yang melibatkan pengaliran bawah tanah di daerah kars (Srijono dkk., 2011).

Dolina di Gunungkidul biasanya terbentuk karena subsidence. frekuensi penurunan muka tanah bisa tinggi (BPBD Kab. Gunungkidul, 2018), berkaitan dengan kondisi fisik lahan maupun tanah/batuan. Pembentukan dolina dapat dimulai dengan amblesan, dan berkembang baik secara alami maupun akibat campur tangan manusia (Delle dkk., 2010).

\section{METODOLOGI}

Survei hidrogeologi lapangan diawali dengan mencari lokasi terdapatnya dolina, kemudian dilakukan deskripsi geologi serta dilengkapi dengan pengambilan sampel air. Penelitian kualitas air dilakukan dengan pengukuran suhu, $\mathrm{pH}$, TDS serta EC air dolina menggunakan peralatan merek Hanna (Gambar 2). Sampel air dolina diambil dalam dua periode, yaitu pada musim kemarau dan musim hujan. Sebanyak 10 dolina telah dipilih untuk diambil sampel airnya, mewakili dua sub sistem, yaitu pada SSH Panggang dan SSH Wonosari-Baron. Dolina yang terpilih adalah dolina yang memiliki volume cukup besar dan representatif, baik pada musim hujan maupun kemarau. Selanjutnya, sampel air diuji di laboratorium BBTKLPP untuk mengetahui sifat fisik dan kimia airnya, antara lain parameter TDS, kekeruhan, warna serta kandungan ion.

Analisis kandungan ion dilakukan menggunakan beberpa diagram hidrokimia, antara lain diagram Piper serta grafik hubungan antar ion. Analisis ini dimaksudkan untuk mengetahui fasies kimia air serta interpretasi beberapa proses yang mempengaruhi hidrokimia air dolina.

\section{HASIL}

\section{Kondisi Dolina}

Dolina banyak dijumpai pada bentang alam kars Gunungsewu, pada ketiga sub sistem hidrogeologi. Dari survei hidrogeologi ditemukan 45 dolina (Tabel 1). Morfologi dolina tersebut memiliki ukuran kecil (diameter $<50 \mathrm{~m}$ )

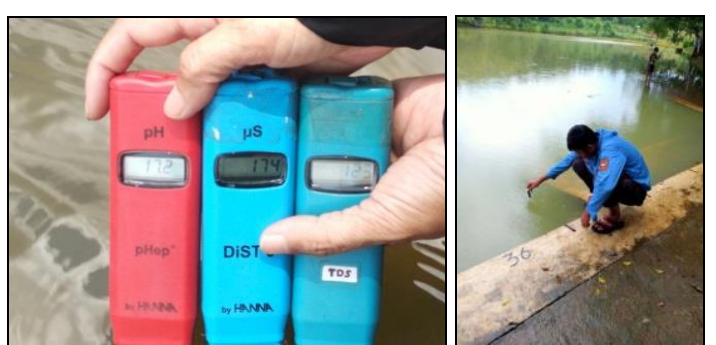

Gambar 2. Peralatan hidrokimia yang digunakan dalam penelitian. 

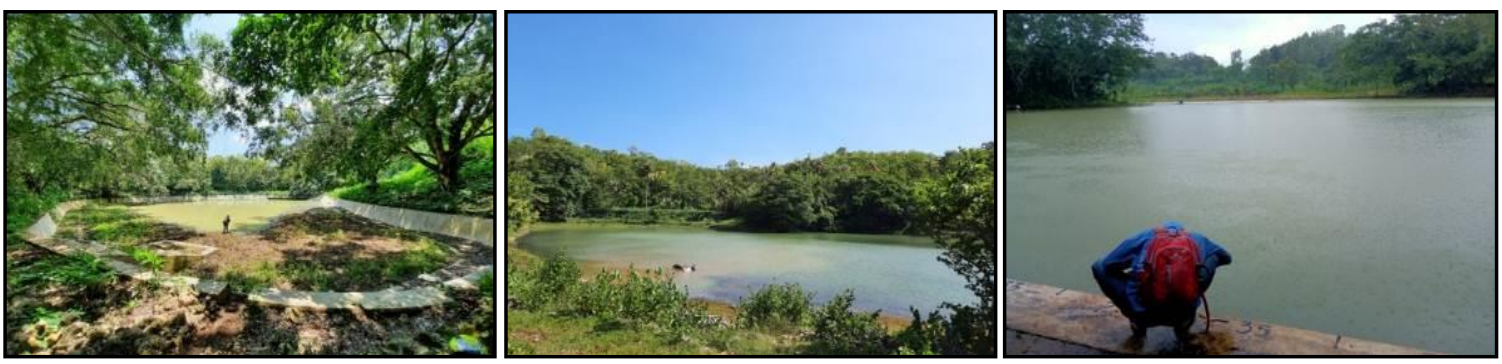

Gambar 3. Contoh dolina yang berdimensi kecil dijumpai di Sambi (D7; kiri) dan Palgading (D10; tengah), sedangkan contoh dolina yang berukuran besar, dengan volume air yang besar sepanjang tahun dapat dijumpai di Namberan (D30; kanan).

Tabel 1. Dolina yang dijumpai di daerah penelitian.

\begin{tabular}{clclcl}
\hline Kode & \multicolumn{1}{c}{ Dolina } & Kode & \multicolumn{1}{c}{ Dolina } & Kode & \multicolumn{1}{c}{ Dolina } \\
\hline D1 & Ploso & D16 & Luweng Lor & D31 & Monggol \\
D2 & Gading & D17 & Jurangjero & D32 & Klepu \\
D3 & Sumber & D18 & Gandrung & D33 & Pengos \\
D4 & Miriledok & D19 & Warak & D34 & Sogo \\
D5 & Gandu & D20 & Pakem & D35 & Gadel \\
D6 & Dendengwelut & D21 & Towet & D36 & Depok \\
D7 & Sambi & D22 & Sudang & D37 & Sumuran \\
D8 & Jombor & D23 & Dondong & D38 & Weru \\
D9 & Klapok & D24 & Ngrandu & D39 & Wuni \\
D10 & Palgading & D25 & Kepek & D40 & Soko \\
D11 & Karangnongko & D26 & Jambeanom & D41 & Melengan \\
D12 & Klampok & D27 & Suci & D42 & Omang \\
D13 & Makam & D28 & Winong & D43 & Sade \\
D14 & Jalin & D29 & Boromo & D44 & Belik \\
D15 & Sumurwuni & D30 & Namberan & D45 & Besole \\
\hline
\end{tabular}

\section{Fasies Hidrokimia}

Fasies airtanah penting diketahui untuk melihat kualitas air maupun proses hidrokimia yang mempengaruhinya. Hiscock (2005) menyatakan bahwa analisis fasies air tanah sangat bermanfaat dalam melakukan identifikasi proses-proses hidrogeokimia pada setiap zona airtanah yang dicirikan oleh kandungan ion-ion terlarut. Oleh karenanya, fasies hidrokimia air dolina juga dapat dikaji untuk mengetahui proses hidrokimia pada dolina dan hubungannya dengan airtanah sekitarnya

Data EC air dolina serta hasil uji kandungan ion mayor $\left(\mathrm{Na}^{+}, \mathrm{K}^{+}, \mathrm{Ca}^{2+}, \mathrm{HCO}_{3}{ }^{-}, \mathrm{SO}_{4}{ }^{2-}, \mathrm{Cl}^{-}\right)$dan ion minor $\left(\mathrm{NO}_{3}{ }^{-}\right.$dan $\left.\mathrm{PO}_{4}{ }^{2-}\right)$ disajikan pada Tabel 2. Selanjutnya, andungan ion mayor dalam air dolina dianalisis untuk mengetahui fasies kimianya. Hasil analisis menunjukkan bahwa fasies hidrokimia pada musim kemarau didominasi oleh fasies $\mathrm{Ca}$, Na-bikarbonat, sedangkan pada musim hujan didominasi oleh fasies Ca-bikarbonat. Dominasi fasies Cabikarbonat pada musim hujan menandai bahwa disolusi batuan tetap berlangsung pada waktu musim hujan, walaupun pengayaan unsur ini belum jelas.
Plot data hidrokimia air yang diteliti pada diagram Piper menunjukkan bahwa pada musim kemarau, air dolina termasuk dalam kelas 5 (tipe $\mathrm{CaHCO}_{3}$ ) dan kelas 9 (tipe campuran), dan ketika musim hujan air dolina pada umumnya berubah menjadi kelas 5 saja (tipe $\mathrm{CaHCO}_{3}$ ) (Gambar 4 dan Tabel 3). Perubahan ini menunjukkan bahwa musim (curah hujan) mengakibatkan dilution pada air dolina.

Dari diagram Piper tampak adanya pergeseran tipe air dolina dari kelas 5 dan 9 menjadi kelas 5 dengan perubahan musim kemarau ke musim hujan. Plot air pada kedua kelas itu juga menandai bahwa proses hidrokimia yang dominan pada air dolina adalah leaching (pencucian) air yang biasanya dipengaruhi oleh disolusi mineral batuan (Listyani dan Peni, 2020). Plot data pada kelas tersebut juga menandai pelapukan karbonat sebagai proses hidrokimia yang dominan (Singh dkk., 2020).

Hidrokimia air dolina juga ditentukan oleh berbagai proses hidrokimia, terutama pelapukan dan pelarutan mineral, selain penguapan dan pengaruh yang kecil dari proses antropogenik. Curah hujan/ presipitasi merupakan proses dominan yang mengakibatkan pengenceran selama musim hujan.

\section{PEMBAHASAN}

\section{Proses Hidrokimia}

Pelapukan dan Disolusi

Aspek hidrokimia dapat dikaji dari analisis bivariat dengan menggunakan korelasi scatter plot beberapa ion yang terkandung dalam air (Singh dkk., 2020). Gambar 5 merupakan grafik hubungan antara kandungan ion $\mathrm{Na}^{+}+\mathrm{K}^{+}$ terhadap total kation (Tz). Gambar ini menandai bahwa pada musim kemarau pelapukan mineral silikat maupun karbonat lebih dominan dibandingkan pada waktu musim hujan. Proses 
pertukaran ion tidaklah dominan pada air dolina yang diteliti, menunjukkan bahwa air tersebut tidak memiliki waktu tinggal yang cukup lama. Walaupun demikian, scatter plot pada Gambar 5 tersebut menunjukkan bahwa air pada musim kemarau memiliki variasi yang lebih lebar dibandingkan pada musim hujan. Scatter plot data yang mendekati garis 2:1 menandai bahwa air pada musim kemarau merupakan hasil dari disolusi batuan lapuk dengan interaksi yang lebih lama.

Tabel 2. Data EC ( $\mu \mathrm{S} / \mathrm{cm})$ dan kandungan unsur/seyawa kimia $(\mathrm{mg} / \mathrm{L})$ air dolina.

\begin{tabular}{|c|c|c|c|c|c|c|c|c|c|c|c|c|c|c|c|c|c|c|c|c|}
\hline & \multicolumn{10}{|c|}{ Musim Kemarau } & \multicolumn{10}{|c|}{ Musim Hujan } \\
\hline Dolina & $\mathrm{Ca}^{2+}$ & $\mathrm{Na}^{+}$ & $\mathrm{K}^{+}$ & $\mathrm{Mg}^{2+}$ & $\mathrm{HCO}_{3}^{-}$ & $\mathrm{SO}_{4}^{2+}$ & $\mathrm{Cl}$ & $\mathrm{NO}_{3}^{-}$ & $\mathrm{PO}_{4}{ }^{2-}$ & EC & $\mathrm{Ca}^{2+}$ & $\mathrm{Na}^{+}$ & $\mathrm{K}^{+}$ & $\mathrm{Mg}^{2+}$ & $\mathrm{HCO}_{3}^{-}$ & $\mathrm{SO}_{4}{ }^{2-}$ & $\mathrm{Cl}^{-}$ & $\mathrm{NO}_{3}^{\circ}$ & $\mathrm{PO}_{4}{ }^{2-}$ & EC \\
\hline D6 & 27,9 & 8 & 6 & 8,22 & 146 & 6 & 7,0 & 0,09 & 2,74 & 248 & 17,6 & 10 & 4 & 2,43 & 68,3 & 16 & 0,6 & 0,1 & 0,26 & 148 \\
\hline D15 & 54,4 & 25 & 4 & 5,8 & 250,1 & 8 & 6 & 0,94 & 0,39 & 418 & 11,2 & 3 & 2 & 3,4 & 47,5 & 20 & 0,6 & 0,21 & 0,59 & 70 \\
\hline D21 & 26,3 & 25 & 6 & 2,89 & 122 & 2 & 8,5 & 2,72 & 0,31 & 204 & 12,8 & 7 & 3 & 4,37 & 59,4 & 10 & 0,6 & 0,93 & 0,15 & 116 \\
\hline D26 & 38,3 & 59 & 8 & 1,93 & 189,1 & 9 & 32 & 0,99 & 1,58 & 304 & 16,7 & 10 & 4 & 2,42 & 59,4 & 10 & 0,6 & 0,46 & 0,08 & 100 \\
\hline D28 & 68,7 & 93 & 13 & 1,45 & 350,4 & 8 & 42 & 0,85 & 4,13 & 374 & 20,7 & 23 & 5 & 1,45 & 97,9 & 9 & 6,5 & 1,7 & 0,15 & 174 \\
\hline D29 & 50,5 & 82 & 9 & 2,42 & 274,5 & 8 & 37 & 1,54 & 6,01 & 322 & 15,9 & 7 & 3 & 1,93 & 77,2 & 10 & 0,6 & 0,17 & 0,1 & 122 \\
\hline D30 & 27,2 & 49 & 6 & 4,35 & 140,3 & 8 & 17,5 & 0,5 & 0,19 & 296 & 19,1 & 7 & 3 & 1,93 & 68,3 & 10 & 0,6 & 0,01 & 0,87 & 132 \\
\hline D31 & 27,5 & 25 & 4 & 1,45 & 140,3 & 2 & 6 & 2,51 & 0,31 & 136 & 14,3 & 10 & 3 & 1,45 & 68,3 & 10 & 0,6 & 0,04 & 0,11 & 110 \\
\hline D32 & 41,2 & 59 & 27 & 9,15 & 267,1 & 16 & 12,5 & 0,23 & 1,55 & 156 & 16,7 & 13 & 4 & 1,45 & 74,2 & 6 & 2 & 0,58 & 0,49 & 104 \\
\hline D42 & 11,1 & 31 & 7 & 1,45 & 91,5 & 4 & 10,5 & 2,01 & 0,81 & 151 & 19,9 & 10 & 4 & 0,48 & 80,1 & 8 & 0,6 & 0,15 & 0,22 & 116 \\
\hline
\end{tabular}

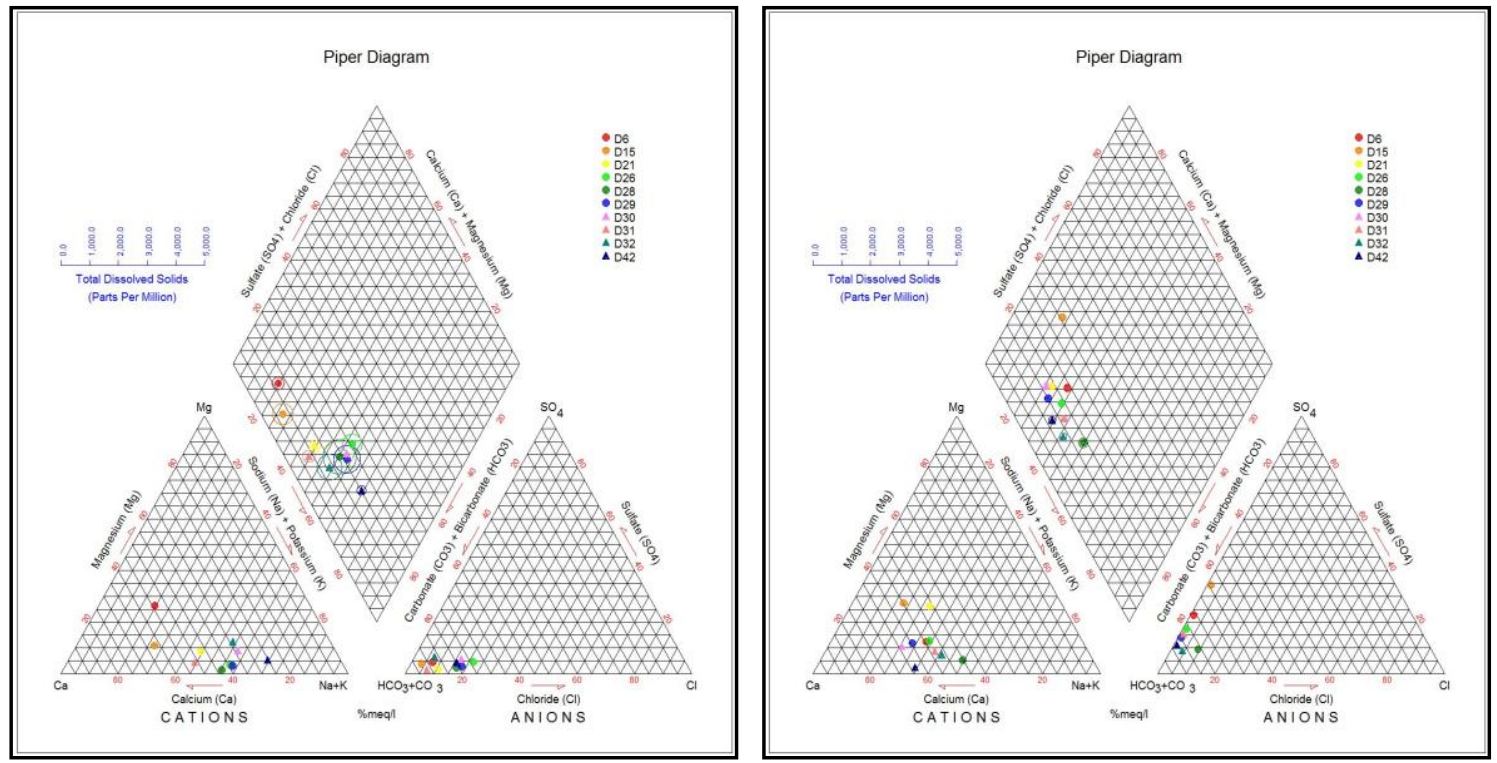

Gambar 4. Diagram Piper air dolina musim kemarau (kiri) dan musim hujan (kanan).

Tabel 3. Pembagian fasies air pada diagram Piper.

\begin{tabular}{|c|c|c|}
\hline \multirow{4}{*}{ Diagram Piper } & \multicolumn{2}{|c|}{ Fasies } \\
\hline & No. & Keterangan \\
\hline & 5 & $\begin{array}{l}\text { Tipe kalsium bikarbonat }\left(\mathrm{Ca}-\mathrm{HCO}_{3}\right) \text { dengan } \\
\text { kekerasan karbonat (alkalinitas sekunder) }>50 \% \text {, } \\
\text { didominasi oleh unsur alkali tanah }\left(\mathrm{Ca}^{2+}+\mathrm{Mg}^{2+}\right) \text { dan } \\
\text { asam lemah }\left(\mathrm{CO}_{3}{ }^{2-}+\mathrm{HCO}_{3}^{-}\right) \text {. }\end{array}$ \\
\hline & 9 & $\begin{array}{l}\text { Tipe campuran }\left(\mathrm{Ca}, \mathrm{Na}-\mathrm{HCO}_{3}\right) \text {, kandungan kation } \\
\text { dan anion seimbang, tak ada yang melebihi } 50 \% \text {. }\end{array}$ \\
\hline
\end{tabular}



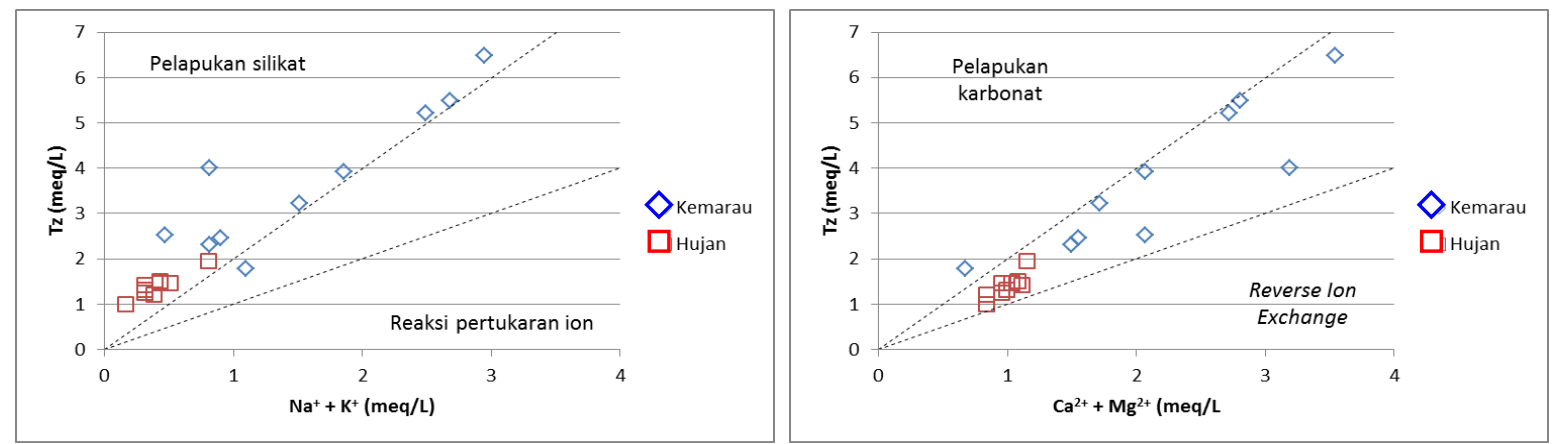

Gambar 5. Scatter diagrams tracing terhadap hidrokimia air dolina yang diteliti.

Gambar 5 menunjukkan bahwa pelapukan mineral lebih dominan terjadi pada musim kemarau, baik pelapukan mineral silikat maupun mineral. Dari grafik tersebut bisa diinterpretasikan adanya material lempungan (silikat) yang lapuk dan terlarut dalam air dolina. Material lempungan itu bisa berasal dari pelapukan mineral pengotor dalam batugamping atau dari tanah hasil pelapukan batupasir karbonatan atau batupasir tufan. Di daerah penelitian juga dijumpai sisipan batupasir tufan walaupun perlapisannya hanya tipis (Gambar 6). Pelapukan silikat lebih mudah terjadi pada musim kemarau, menandai interaksi yang lebih lama antara air dan mineral batuan. Adapun interaksi air-batuan relatif singkat pada musim hujan karena air hujan menjadi lebih berpengaruh terhadap hidrokimia air dolina.

Di kawasan kars, proses disolusi batuan merupakan hal yang dominan terjadi pada batugamping, karena batuan karbonat ini mudah larut. Hasil disolusi ini akan sangat mempengaruhi fasies air di daerah kars, baik air permukaan maupun airtanah. Batugamping yang dominan menyusun daerah penelitian adalah batugamping terumbu, pada umumnya berstuktur masif dan memperlihatkan gejala lapies serta lubang pelarutan (Gambar 7). Karimi dkk. (2005) menyatakan kekuatan interaksi air-batuan dalam sistem akuifer kars dengan melihat hubungan antara EC dan ion utama yang terlarut dalam air di daerah kars. Nilai EC menandai banyaknya TDS dalam air. Ion utama yang biasa digunakan untuk analisis hidrokimia daerah kars di antaranya adalah $\mathrm{Ca}^{2+}$, $\mathrm{Mg}^{2+}$, dan $\mathrm{HCO}_{3}^{-}$.

Rasio $\mathrm{Ca}^{2+}$ dan $\mathrm{Mg}^{2+}$ juga berguna untuk mengetahui disolusi kalsit maupun dolomit dalam air. Rasio $\mathrm{Ca}^{2+} / \mathrm{Mg}^{2+}>1$ seperti yang ditunjukkan pada air dolina yang diteliti

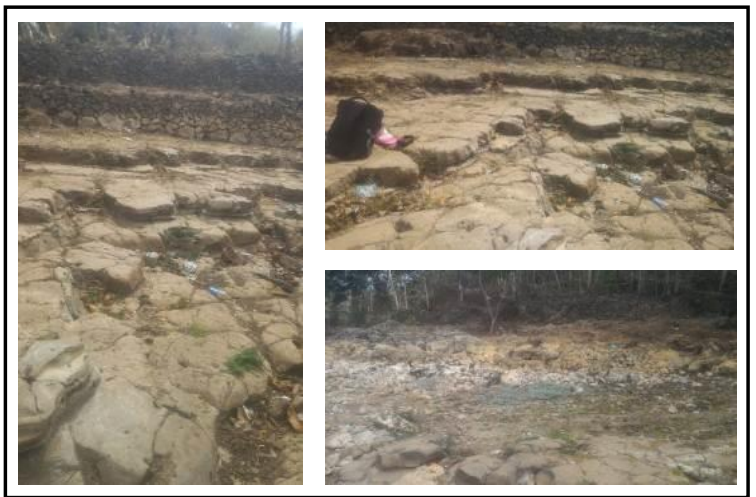

Gambar 6. Singkapan batupasir tufan di sekitar dolina Boromo (D29).

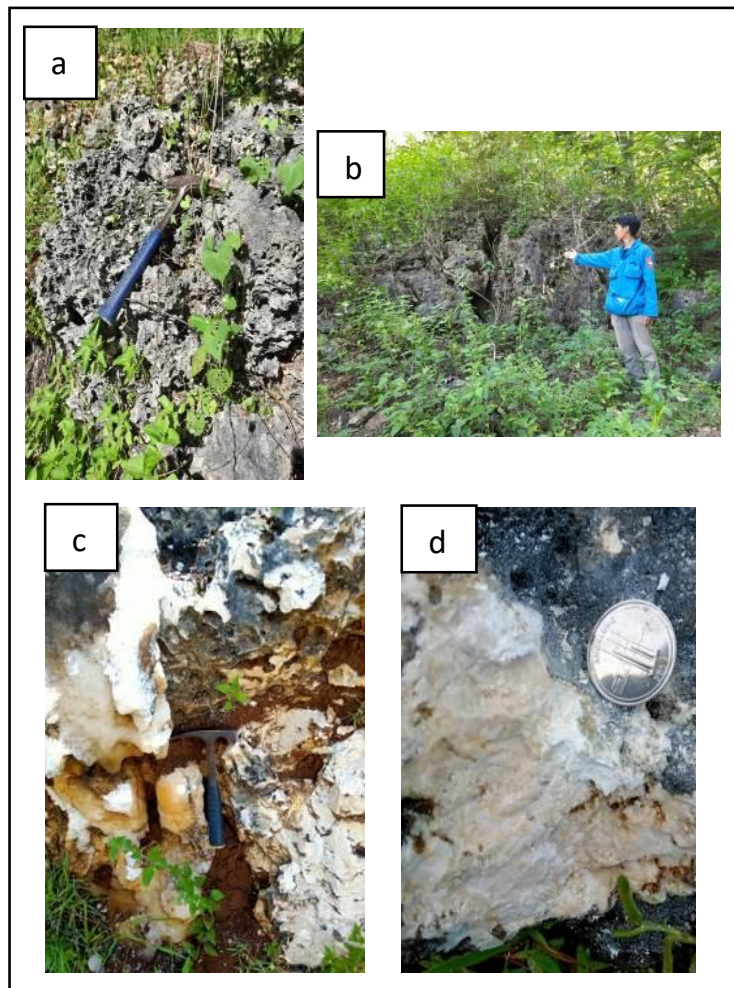

Gambar 7. Singkapan batugamping terumbu di sekitar (a) dolina Sumber (D3); (b) dolina Miriledok (D4); (c) Dendengwelut (D6); dan (d) Dolina Sumuran (D37). 
(Gambar 8a) menandai bahwa disolusi kalsit merupakan sumber utama ion dalam air dolina, atau dengan kata lain disolusi kalsit merupakan proses hidrokimia yang utama (Kumar dan Singh, 2015 vide Mallick dkk., 2020).

Plot $\mathrm{Ca}^{2+}+\mathrm{Mg}^{2+}$ vs $\mathrm{HCO}_{3}{ }^{-}+\mathrm{SO}_{4}{ }^{2-}$ digunakan untuk menganalisis proses pertukaran ion. Penyimpangan terhadap garis 1:1 menandai adanya proses pertukaran ion (Gambar 8b). Dengan demikian, selain adanya disolusi kalsit, proses pertukaran ion juga terjadi pada air dolina, terlebih pada musim kemarau.

\section{Evaporasi dan Pengayaan}

Laju proses evaporasi yang tinggi biasanya ditandai dengan kandungan $\mathrm{Cl}^{-}$yang besar (Mallick dkk., 2020). Akan tetapi, hal ini tidak teramati pada air yang diteliti. Ini berarti bahwa proses evaporasi tidak dominan terjadi. Dibandingkan musim hujan, proses evaporasi nampak lebih intensif di musim kemarau.

Di lain pihak, scatter diagram antara EC dan ion $\mathrm{Na}^{+} / \mathrm{Cl}^{-}$menunjukkan pelapukan mineral silikat lebih dominan dibandingkan reaksi airbatuan. Peningkatan rasio $\mathrm{Na}^{+} / \mathrm{Cl}^{-}$terhadap EC (Gambar 9a) menunjukkan kelebihan $\mathrm{Na}^{+}$terkait dengan pelapukan silikat (Singh dkk., 2020). Pada Gambar 9b, excess $\mathrm{Na}^{+}$dibanding $\mathrm{Cl}^{-}$di musim kemarau (plot data di atas garis equiline 1:1) menandai pelapukan silikat sebagai proses dominan (Singh dkk., 2020), sedangkan plot data yang mendekati garis 1:1 yang dominan terjadi pada musim hujan dapat menandai adanya disolusi halit. Plot data yang berada di bawah garis equiline menunjukkan proses evaporasi, namun tak ada sampel yang jelas menunjukkan hal ini. Plot data pada Gambar 9c yang terletak di atas 1:1 menunjukkan excess alkali dan formasi alkali karbonat (Mallick dkk., 2020).

Laju proses evaporasi yang tinggi biasanya ditandai dengan kandungan $\mathrm{Cl}^{-}$yang besar (Mallick dkk., 2020). Akan tetapi, hal ini tidak teramati pada air yang diteliti. Ini berarti bahwa proses evaporasi tidak dominan terjadi. Dibandingkan musim hujan, proses evaporasi nampak lebih intensif di musim kemarau.

Gambar 9 ini menandai bahwa pengayaan hidrokimia lebih dipengaruhi oleh pelapukan daripada interaksi air-batuan. Hal ini sangat mungkin terjadi karena air yang diteliti merupakan air permukaan yang memiliki residence time relatif singkat. Akan tetapi, apabila dibandingkan antara dua musim, maka plot data hidrokimia menunjukkan bahwa musim kemarau memberikan variasi yang lebih lebar. Hal ini bisa terjadi apabila reaksi pelapukan maupun interaksi air-batuan yang mengakibatkan karakteristik hidrokimia air di musim kemarau terjadi pada waktu yang lebih panjang.

\section{Aktivitas Antropogenik}

Aktivitas antropogenik memberi kontribusi $\mathrm{Na}^{+}$ yang tinggi dalam airtanah (Mallick dkk., 2020). Kandungan $\mathrm{Na}^{+}$dalam air yang diteliti berkisar 8 - 93 ppm pada musim kemarau, dan $3-23$ ppm pada musim hujan. Ini berarti bahwa pencemaran antropogenik dilihat dari kandungan $\mathrm{Na}^{+}$belum begitu terlihat.

Sementara itu, Mallick dkk. (2020) memberikan petunjuk tentang pengaruh antropogenik berdasarkan senyawa nitrat $\left(\mathrm{NO}_{3}{ }^{-}\right)$. Menurutnya, sulfat dalam airtanah mungkin terkait dengan disolusi mineral gipsum/anhidrit, sementara itu pupuk, limbah pertanian/kota dan
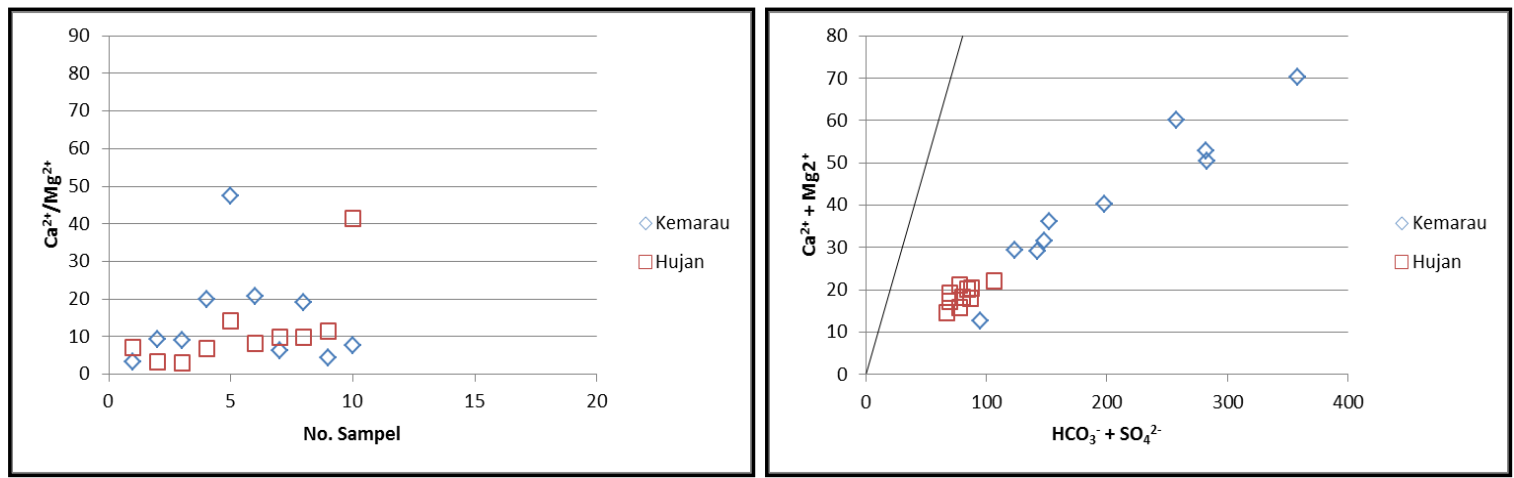

Gambar 8. Hubungan beberapa parameter hidrokimia: a. Plot $\mathrm{Ca}^{2+} / \mathrm{Mg}^{2+}$ vs no sampel, b.Plot $\mathrm{Ca}^{2+}+\mathrm{Mg}^{2+} v s$ $\mathrm{HCO}_{3}{ }^{-}+\mathrm{SO}_{4}{ }^{2-}$ 


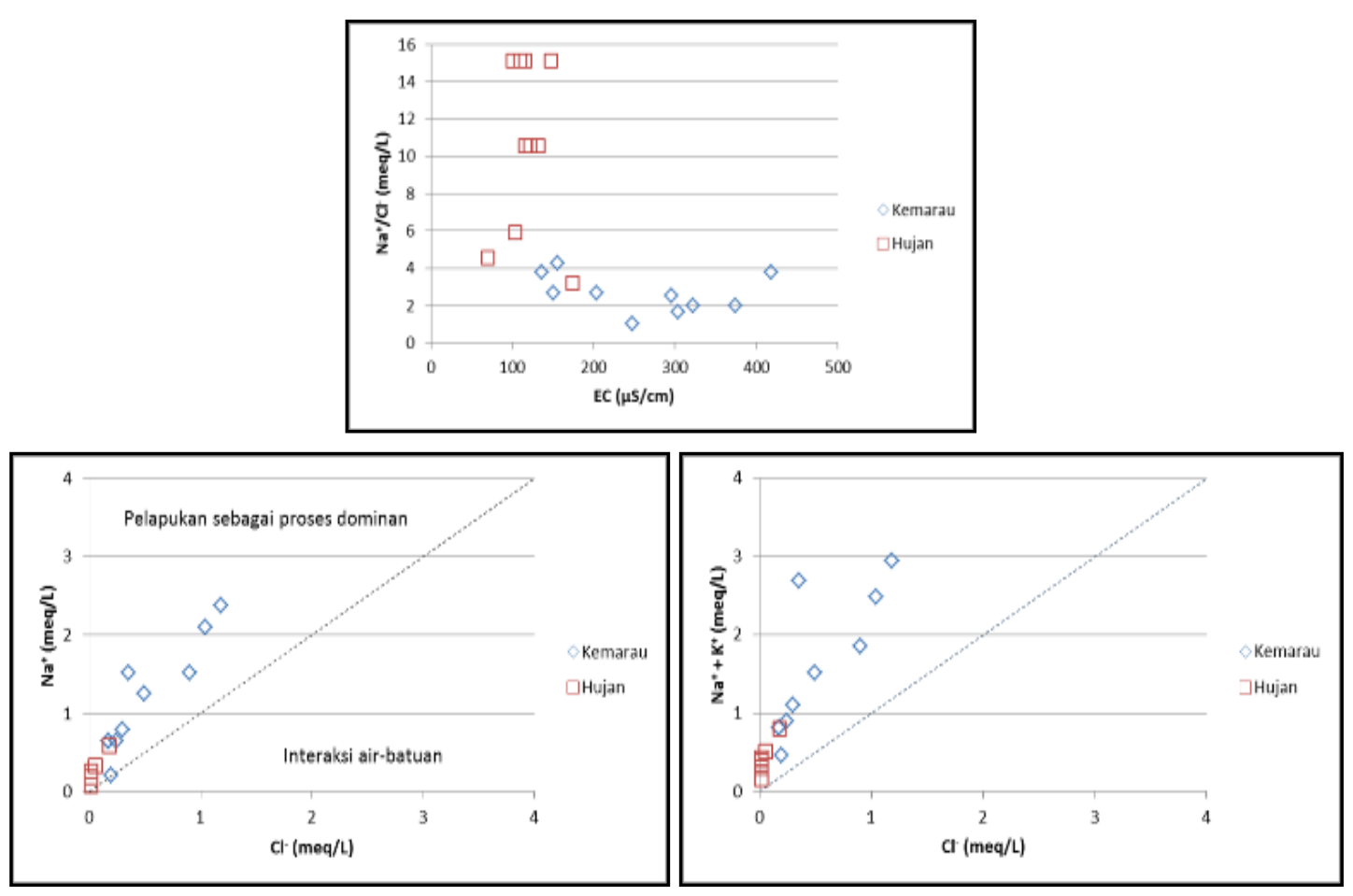

Gambar 9. Scatter diagram untuk mengetahui interpretasi proses hidrokimia dalam air yang diteliti.

pencucian limbah akan memberikan kontribusi senyawa nitrat dalam airtanah. Adapun kandungan nitrat pada air dolina yang diteliti hanya sedikit, yaitu berkisar $0,09-2,72 \mathrm{ppm}$ pada musim kemarau dan 0,01 - 1,7 ppm pada musim hujan. Namun demikian, hubungan kandungan senyawa ini terhadap unsur $\mathrm{K}+$ dan Cl- dapat dianalisis untuk melihat pengaruh antropogenik (Singh dkk., 2020; Gambar 10).

Kadar $\mathrm{K}^{+}$dan $\mathrm{NO}_{3}{ }^{-}$cukup rendah di air dolina kecuali pada D32 (27 ppm), namun hubungan antara keduanya tidak kentara. Nilai $\mathrm{K}^{+}$yang rendah mungkin terjadi karena batuan silika tidak mendominasi daerah penelitian. Beberapa plot sampel yang berada di sekitar garis uniline dapat berarti adanya pelepasan ion terkait dengan penggunaan pupuk pertanian berbasis $\mathrm{K}^{+}$dan $\mathrm{NO}_{3}^{-}$. Hal ini terjadi baik pada musim kemarau maupun musim hujan.

Konsentrasi $\mathrm{Cl}^{-}$dalam air dolina di musim hujan pada umumnya lebih rendah dibanding pada musim kemarau. Hubungan antara kandungan $\mathrm{Cl}^{-}$dan $\mathrm{NO}_{3}{ }^{-}$di musim kemarau kurang terlihat, namun sangat kuat di musim hujan. Hal ini dapat menunjukkan pengaruh antropogenik. Aktivitas antropogenik yang dapat mempengaruhi hidrokimia air ini dapat berasal dari bahan kimia seperti pupuk, bahan pemutih atau material industri lainnya (Singh dkk.,
2020). Akan tetapi, menurut plot data sampel air yang diteliti pada Gambar 10, sebagian besar ion $\mathrm{NO}_{3}^{-}$yang terkandung dalam air tersebut berasal dari deposisi anion asam. Hanya sedikit sampel pada musim kemarau yang mungkin diakibatkan oleh dampak antropogenik dari pupuk (fertilizer), ditandai dengan pengayaan $\mathrm{Cl}^{-}$dan nitrat.

Korelasi positif antara kandungan $\mathrm{Cl}^{-}$dengan unsur $\mathrm{Ca}^{2+}, \mathrm{Mg}^{2+}$ dan $\mathrm{SO}_{4}{ }^{2-}$ menunjukkan adanya pengaruh antropogenik yang terjadi bersamaan dengan reverse ion exchange (Singh dkk., 2020). Hal ini bisa diakibatkan oleh bubuk pemutih atau limbah indutri yang menghasilkan ion $\mathrm{Cl}^{-}$. Di daerah penelitian, hal ini hanya terjadi pada hubungan $\mathrm{Cl}^{-}$dengan $\mathrm{Ca}^{2+}$, terutama pada musim kemarau (Gambar 11). Korelasi yang kuat dan positif ini menunjukkan adanya pengaruh antropogenik pada kualitas air dolina di kedua musim, terutama pada musim kemarau. Namun, pengaruh ini tidaklah besar, terbukti dengan hubungan $\mathrm{Cl}^{-}$terhadap $\mathrm{Mg}^{2+}$ dan $\mathrm{SO}_{4}{ }^{2-}$ cenderung negatif dan rendah.

Pengaruh aktivitas antropogenik yang tidak besar juga didukung oleh hubungan $\mathrm{NO}_{3-}$ dan $\mathrm{PO}_{4}{ }^{2-}$ (Gambar 12). Korelasi antar dua jenis ion tersebut menunjukkan tingkatan yang rendah, baik pada musim kemarau maupun hujan. Fosfat dan nitrat biasanya bersumber dari dekomposisi 

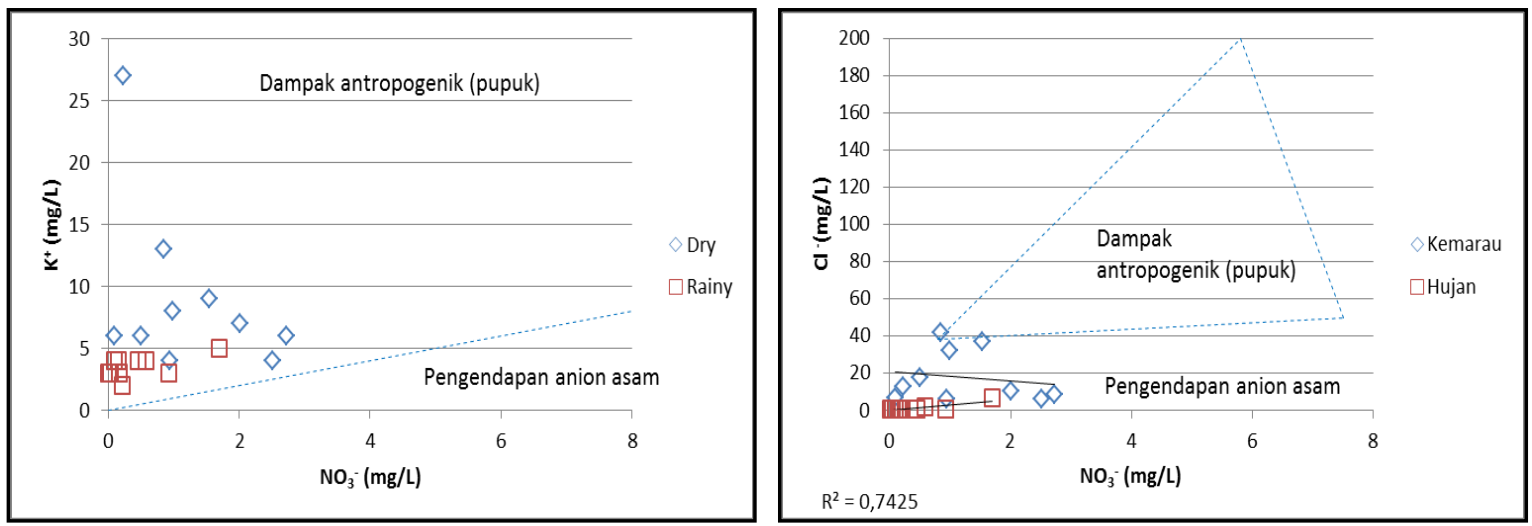

Gambar 10. Scatter diagram untuk mengetahui proses antropogenik.
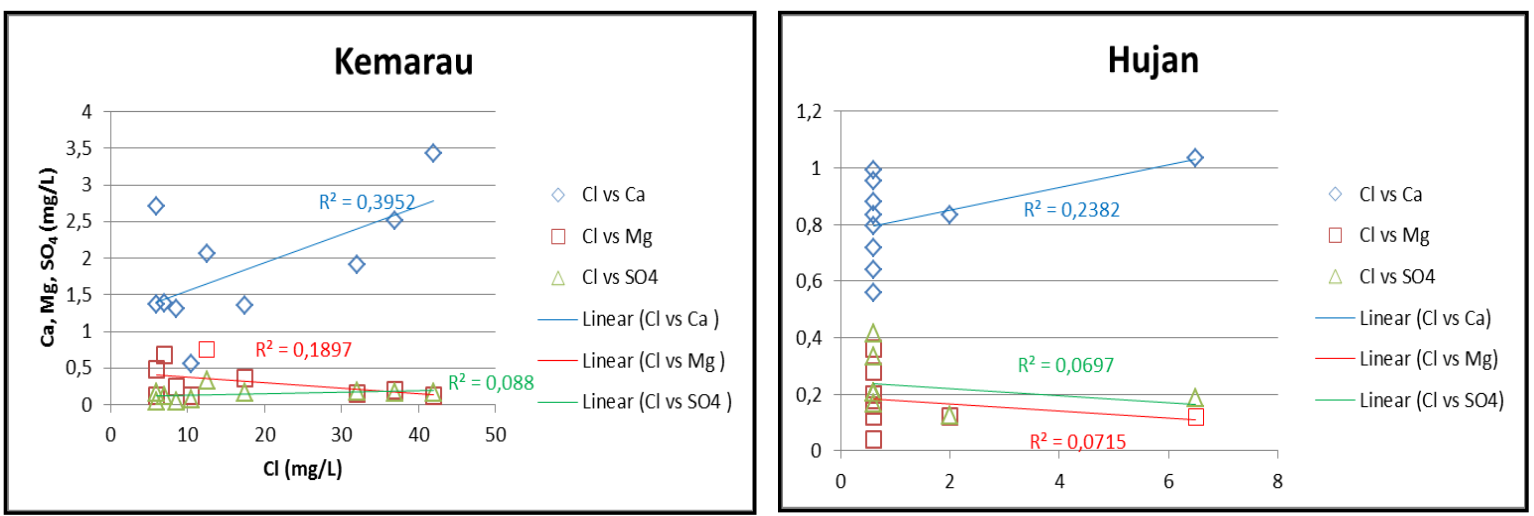

Gambar 11. Korelasi positif antara $\mathrm{Cl}^{-}$dengan kation $\mathrm{Ca}^{2+}, \mathrm{Mg}^{2+}$ dan $\mathrm{SO}_{4}{ }^{2-}$ dalam air dolina yang diteliti.

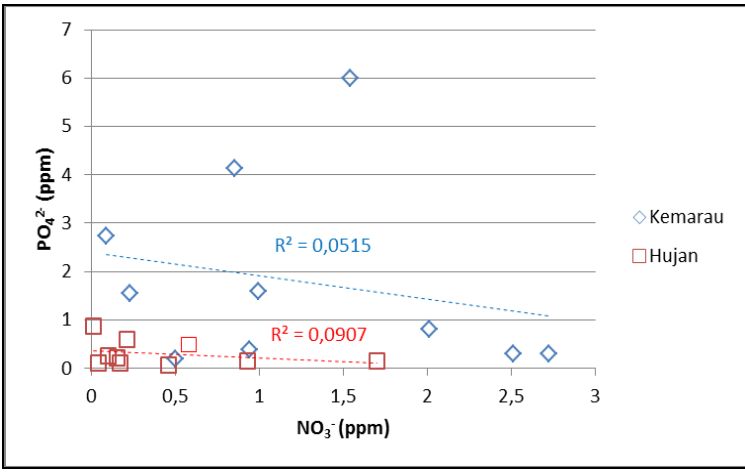

Gambar 12. Korelasi nitrat dan fosfat untuk mengetahui pengaruh proses antropogenik.

tanaman atau organisme mikro, selain berasal dari pencemaran pupuk. Korelasi yang rendah dari hubungan keduanya dapat menandai bahwa proses dekomposisi tumbuhan atau kotoran binatang serta pencemaran dari pupuk atau limbah belum berpengaruh kuat. Artinya, aktivitas antropogenik bukan merupakan proses hidrokimia yang dominan.

\section{KESIMPULAN}

Hidrokimia air dolina pada SSH Panggang dan Wonosari - Baron telah diteliti, khususnya pada
10 dolina terpilih. Sampel diambil pada musim kemarau terlebih dahulu, lalu pada musim hujan, dan kemudian dianalisis melalui beberapa diagram hidrokimia.

Hasil penelitian menunjukkan bahwa karakteristik hidrokimia air dolina menunjukkan fasies $\mathrm{Ca}$, Na-bikarbonat pada musim kemarau, dan pada musim hujan secara umum menunjukkan fasies Ca-bikarbonat. Karakteristik hidrokimia ditentukan oleh berbagai proses hidrokimia, yang didominasi oleh pelapukan dan pelarutan mineral, selain penguapan dan pengaruh yang kecil dari proses antropogenik. Curah hujan/presipitasi merupakan proses dominan selama musim hujan yang mengakibatkan pengenceran.

\section{UCAPAN TERIMA KASIH}

Penulis mengucapkan terimakasih kepada ITNY atas pendanaan penelitian internal 2020 sehingga tulisan ini dapat dipublikasikan.

\section{DAFTAR PUSTAKA}

BPBD Kab. Gunungkidul, 2018. Data on

Subsidences Distribution in 2017. Yogyakarta: Center for Data and Reporting 
on Regional Disaster Management Agencies Gunungkidul.

Delle, M.R., Federico, A., dan Parise, M., 2010. Sinkhole genesis and evolution in Apulia, and their interrelations with the anthropogenic environment. Natural Hazards and Earth System Science, 4(5/6), hal.74775.

Ford, D.C., dan Williams, D., 2007. Karst Hydrogeology dan Geomorphology. England: John Wiley dan Sons.

Geological Survey, 2019. Karst Landforms. https://www.gsi.ie.

Hiscock, K.M., 2005. Hydrogeology, Principles and Practice. United States of America: Blackwell Publishing.

Karimi, H., Raeisi, E., Bakalowicz, M., 2005. Characterizing the Main Karst Aquifers of the Alvand Basin, Northwest of Zagros, Iran, by A Hydrogeochemical Approach. Hydrogeology Journal, 13, 787-799. https://doi.org/10.1007/s10040-004-0350-4.

Kusumayudha, S.B., 2002. Sistem Hidrogeologi Gunung Sewu, dalam Sumberdaya Geologi Daerah Istimewa Yogyakarta dan Jawa Tengah. Proceeding 31st Annual Convention Indonesian Association of Geologist.

Kusumayudha, S.B., Setiawan, J., Ciptahening, A.N., dan Septianta, P.D., 2015. Geomorphologic Model of Gunungsewu Kars, Gunung Kidul Regency, Yogyakarta Special Territory, Indonesia: The Role of Lithologic Variation and Geologic Structure. Journal of Geological Resource and Engineering, 3(1), hal.1-7.

Listyani R.A., T. dan Peni, S.N., 2020. Chemical Type Variation of Groundwater in Borobudur and Surroundings Area, Magelang District. Proceedings of ICENIS 2020, E3S Web of Conferences 202, 12005 (2020), hal.1-13, https://doi. org/10.1051/
Mallick, J., Singh, C.K., AlMesfer, M.K, Kumar, A., Khan, R.A., Islam, S., dan Rahman, A., 2018. Hydro-Geochemical Assessment of Groundwater Quality in Aseer Region, Saudi Arabia. Water, 10, 1847; https://doi.org/10.3390/w10121847.

Pambudi, R.A., Damayanti, A., dan Marko, K., 2018. Distribution Pattern of Cave Entrance Based on Morphometry in Gunung Sewu Karst Landscape. Proceedings of ICENIS 2018 E3S Web of Conferences 73, 04011 (2018). https://doi.org/10.1051/e3sconf/ 20187304011.

Setiawan, T., Isnaini, S., Asghaf, N. M. A. dan Effendi, I., 2018. Sistem Imbuhan Air Tanah Daerah Kars Wonosari - Baron, Kabupaten Gunungkidul, Daerah Istimewa Yogyakarta berdasarkan Analisis Isotop ${ }^{18} \mathrm{O}$ dan ${ }^{2} \mathrm{H}$. Jurnal Lingkungan dan Bencana Geologi, 9(3), hal.143-155, http://jlbg.geologi.esdm.go.id/index.php/jlbg.

Setiawan, T., Isnaini, S., Asghaf, N. M. A. dan Effendi, I., 2019. Karakteristik Interaksi Air $\mathrm{CO}_{2}-\mathrm{CaCO}_{3}$ dan Analisis Sistem Aliran Air Tanah Kars Musim Kemarau di Kab. Gunungkidul, Daerah Istimewa Yogyakarta. Riset Geologi dan Pertambangan, 29(2), hal.171-183. DOI: 10.14203/risetgeotam 2019.v29.1022.

Singh, A., Patel, A.K., Deka, J.P., Kumar, M., 2020. Natural recharge transcends anthropogenic forcing that influences arsenic vulnerability of the quaternary alluviums of the Mid-Gangetic Plain. Clean Water, 3(27), 1-12, https://doi.org /10.1038/s41545-0200075-5.

Srijono, Husein, S., dan Budiadi, E., 2011. Geomorfologi. Buku Ajar. Yogyakarta: Jurusan Teknik Geologi, Fakultas Teknik, Universitas Gadjah Mada. 